\title{
Analysis on the Web Marketing of Foreign Trade Enterprise
}

\author{
Yan Qu \\ Shandong Yingcai University \\ quyan@ycxy.com
}

\begin{abstract}
Small and medium-sized enterprises play a decisive role in economic field in China. However, global economic downturn add Management risk for Chinese Small and medium-sized enterprises, E-commerce with its unique advantages becomes an important channel for these enterprises to exploit overseas market. From the customers - European and American countries user angle, this article analyzed the defeat reason of trade web marketing the small and medium-sized enterprise are facing, and put emphasis on problems existed in the English (or foreign language) Website Construction, especially website positioning, webpage design, search engine optimization and so on to operate a live marketing website with less cost and more good effects in sale promotion.
\end{abstract}

Keywords: Foreign Trade Enterprise, E-commerce, Web marketing, Website construction.

\section{Introduction}

Small and medium sized foreign trade enterprises are divided into two types, one is state-owned or partly state-owned foreign trade companies, the other is recent liberalization of foreign trade rights establishment of private foreign trade enterprises. Two kinds of property nature of the small and medium sized foreign trade enterprises have different "origin", operating status also has different characteristics. But they are in the trend of economic globalization, cooperation in the field of international business plays an increasingly important role. According to State Administration for Industry \&Commerce of the People's Republic of China, there're about 1390.51 million companies registered in State administration for industry and commerce by the end of 2016.3, of which more than $99 \%$ for SMEs; contribution of SMEs to GDP exceeds $60 \%$, the contribution of the import and export trade volume amount to nearly 70\%. But with the economic downturn, the RMB appreciation, rising raw material costs, rising labor costs and other factors caused the total amount of foreign trade enterprises decreased rapidly, SMEs build online English website and turn to overseas customers, which will undoubtedly become an important opportunity for the development of foreign trade enterprises. However, We found that the establishment of enterprises' website, which did not achieve the desired effect after operating for some time, what's the reason for SMEs e-commerce development?

\section{The Reasons For the Failure}

In general, the process of trade is divided into three steps: pre-trade, trade, post-trade. Many foreign companies have launched online marketing, but the result was unsatisfactory, there are several possible reasons for the failure: pre-trade failure refers to the English site failure; trade failure means they didn't pay attention to the relationships with the customers; post-trade failure mainly the lack of integrity leads to loss of customers during the trading.

\section{Pre-trade failure}

Foreign trade enterprises should be fully aware of the important role of website in online marketing strategy, give the site a comprehensive, systematic, professional analysis and made targeted improvements needed according to online marketing strategy in order to play an important role in the overseas market. Before trade, Website building services provider and insufficient promotion is a major cause of foreign trade enterprise network marketing failure for lacking of awareness of the site. 
Trade Website is facing to English-language users, such as domestic export-oriented enterprises English website. Many foreign websites more or less exist the following problems:

Firstly, many foreign trade enterprises website only attention to fancy appearance regardless of functionality and usability of the page; website design is not professional, rough work, lots of English syntax errors, which made foreign customers feel the company is very small, careless and lost the opportunity to work with; website design does not meet the foreign users' browsing habits, which leading to its customers is difficult to find the information you want, thus losing trade opportunities; nobody responds to users timely such as corporate website feedback, online consulting, e-mail consultation; so it is difficult for the company to find buyers; or cheating website optimization, search engine was blocked, resulting in a search engine not found on the site; ignore the foreign local user habits, ignoring the local yellow pages and other well-known sites and buyers commonly used tools; not compatible browsers; do not know the type of browser used by British and American Internet users (such as Firefox), resulting in many export enterprises English website in Firefox appears entirely misplaced, deformation, cannot get the basic site information, which is a serious problem affecting the overseas promotion.

\section{Trade Failure}

China's foreign trade enterprises have misunderstandings when first approached to the United States, they are not familiar with the habit of doing business in the United States and often lead to failure in the first contact. In normal trade transactions, E-mail, telephone, fax, etc. are ways for foreign companies to sell products in the United States, trade commissioner of some companies also use MSN, SKYPE chat and other online tools to contact with customer. Among them, using E-mail to sell products to customers accounted for more than $90 \%$ the proportion of marketing approach. But according to statistics, the United States used to set rejection mailbox function to reject unfamiliar e-mail for fearing the spread of the virus e-mail. therefore, E-mail marketing letters are often disposed of as spam and cannot be concerned. So sending the United States E-mail to sell products cannot work in many cases.

\section{Post-trade Failure}

According to the research results of the Ministry of Commerce China's foreign trade enterprise credit system research shows that in recent years, every year Chinese companies' direct and indirect economic losses amounted to 585.5 billion Yuan because of lacking credit, equivalent to 37\% of China's annual revenue, China National Product thus reducing the total value of at least two percentage points per year. Honesty is cornerstone of the enterprise under market economy. In the context of the financial crisis, the corporation actively establish integrity management system to enhance the integrity of the concept of import and export enterprises, improve product quality and safety, which will undoubtedly enhance the ability to cope with risks. Not only is the company's own credit basis of survival and development, but also related to the credit status of the entire society, the relationship between the credibility of China's foreign trade. After China's accession to the WTO, a good reputation will permit us to participate in international economic and trade exchanges. Situation of enterprises in the export of products subject to serious dishonesty, not only the business itself is included in the blacklist of the importing country, the elimination of export qualifications, but also seriously affected the image and reputation of our business, so that our exports have suffered significant losses. So, in today's international trade, the lack of integrity of the enterprise is difficult to have space for development. And trust in foreign trade business website can be expressed as the degree of trust that the website bring to visitors. It produce a psychological effect when visitors visit the site, which is based on a fuzzy evaluation of people surfing the experience and life experience of the website authenticity, authority, etc. This evaluation can influence the viewer's browsing behavior, which has a great significance on website particular e-commerce site. 


\section{The Strategies to Improve the Network Marketing Ability of Foreign Trade Enterprises}

\section{The Establishment and Promotion of Website from the Perspective of Network Marketing}

\section{Site Location and Good Customer Experience}

The so-called website target is the role played on the web site, what ideas and service would you convey to your target group (the viewer) ? The criteria to evaluate a successful website is its click rate, and whether people wish to buy the company's products or services through the website. An effective corporate website requires us to design a website from the perspective of customer and understand the users' needs, habits fully. For example, in Europe, the number of professional buyers using the yellow pages is bigger than those using network; B2B business platform in some places should use different network marketing programs under customary different regions according to users' habits.

\section{Put Foreign Trade Business Website on Overseas Servers to Ensure Speed}

First, for the European and American customers habits, they are not interested in the site that opened beyond 3 seconds. If your customer groups are mainly from European countries, it is recommended to put your website on U.S server, the United States is the first choice; If your customers are mainly in Asia, we recommend that you put the site in Hong Kong, as an international export Asia, which stand for fastest speed. Secondly, due to the problem of spam mail servers, IP addresses are often shielded abroad, it is recommended that you use overseas companies or overseas mail as your enterprise mailbox, ensuring global transceiver normal.

Focus on the Effect Ways to Promote Trade Website

You must select an effective way to promote your Website.

(1) Email marketing methods

Electronic journals, newsletters, professional service providers of e-mail advertising are the way to promote the use of the largest foreign trade company. It should be noted strategic approach, try not to use attachments, because foreigner usually think attachment has a virus and reject, it cannot reach the promotion effect.

(2) Search engine marketing

Search engine optimization(SEO) promotion can rapidly improve website ranking in the search engine advertising, but the quality of the customer on the basis of a large customer base will be relatively low. Three major search engines are GOOGLE, YAHOO, BAIDU.GOOGLE is the most competitive abroad, so companies should set their own keywords to devote to their target market, which can play an effective search engine promotion effect. You should avoid using free and paid directories and add sites to some excellent sites directory. GOOGLE will take your website to reflect the correct directory users; submit your site in DMOZ and YAHOO directory.

(3) B2B E-commerce Website Promotion

B2B website provides a platform for businesses to publish information for product promotion and advertising, other businesses get useful information and conduct transactions via B2B websites. Many regions have their own well-known national trade platform and industry trade platform in the world, such as www.worldbid.com, www.aaaoe.com (USA Global GUIDEC), etc. These sites help domestic suppliers to achieve highly targeted industry promotion. Chinese famous international trade platforms such as Alibaba, Made in China, Global Sources, China's foreign trade network (www.chinamarket.com.cn), North America Trade Promotion Network (www.usashow.net), Chinese businessmen Network (www.veryebiz. com) and so on.

(4) Web2.0 online marketing.

Web2.0 online marketing such as blog, community, forums, videos and many other promotion methods, you can achieve good results if you keep doing. 
The basis of the establishment and promotion of the English site preparation is a combination of your choosing appropriate keywords for specific product. You can use the free and efficient tool Google AdWords Keyword Tool and English Google.com (the most practical tool).

Pay Attention to Details

(1) Website design style

you should build websites according to the customer base. Such as South Korea's pursuit of web style is delicate, gorgeous, therefore we should designed beautifully pages for the South Korean customers, while European and American site structure, colors are very simple, and therefore concise style, quick navigation settings to be more popular for the European and American customers. Besides,the English translation should be more in line with European habits, it cannot appear Chinese-style English, which will seriously affect the website image.

(2) Trade website page structure and design

Chinese website used to open a new window when clink the hyperlink, and European countries adopted the habit of the current page open; Most foreign trade website fonts are in accordance with Chinese ideas "Times New Roman", but according to studies, Times New Roman font is not foreign websites but "Roman" font, you cannot use a fixed size, which will affect the interaction resistance.

(3) FAQ section on website

Settings for your website FAQ section, answering user feedback (potential) of the key issues to better illustrate the website. This section not only make your site look more formal trade, but also very practical; at the same time, foreign user pay attention to protect privacy, so personal information and privacy on foreign website should be protected strictly.

\section{Strategy to Strengthen Brand confidence}

We must set the rules for the integrity of the foreign trade enterprises, only government agency, media publicity and the vast majority of foreign trade enterprises act together, the companies can really form their own strategy and brand integrity. It is imperative that we put forward suitable foreign trade enterprises rate mechanism to accelerate the construction of foreign trade enterprise credit system , which is a breakthrough.

Firstly, we should strengthen the government's own sense of integrity, the majority of import and export enterprises to actively publicize the relevant policies and regulations in various forms through newspapers, radio, television, etc. to facilitate law-abiding principle advocate, encourage enterprises to consciously abide by the law, the law enforcement environment optimization to create an atmosphere of integrity and law-abiding.

Secondly, increasing efforts to foster corporate integrity, enhance law-abiding awareness, guide enterprises to establish a "brand" awareness and promote the healthy development of foreign trade enterprises.

Finally, establish and improve the supervision and risk management systems, and resolutely combat irregularities illegal enterprises.

\section{Website Credit}

Foreign business users pay more attention to foreign commercials. If you have no detailed description on the English website design, you can easily lose users. we try to follow the rules to give deep impression on users.

(1) Prohibited spam

Domestic foreign trade companies should control the amount of sending sales letter, you'd better send 500 U.S. importers Contact in a loop at the same time and avoid too many sales letters sent that exceed its capacity of business, which resulting in bad faith impression.

(2) ”About us” page.

Your partner generally need to have a comprehensive understanding of your company before registering and finishing the order. Thus, ”About us” page. do not use templates to design, you should 
list your company's personal information, the original intention of the construction site, background and other information clearly, such as the company's location, set-up time and size of the company, the most direct Contacts and so on.

(3)"Contact us" page

The contact information of your company such as telephone, e-mail addresses, instant messaging, online customer service, etc. You should clear these linkages and ensure the effective and can get a reply immediately.

\section{Conclusion}

Small and medium enterprises(SMES) trading with foreigner trade, managers should have deep understanding on the "marketing" , especially on the "network marketing" concept if you want to gain a foothold in foreign trade in the current economic situation;Secondly,you should attention the trade construction principles, foreign trade and contact details of the process, and safeguard the integrity of the system itself, I believe that companies will be able to obtain economic benefits and gain an invincible position in the market.

\section{Acknowledgement}

This research was financially supported by the Shandong Provincial National Science Foundation. China(ZR2015GLOO5)

\section{References}

[1]China's State Administration for Industry, "2016 National Development Report of market players.", http://www.saic.gov.cn.

[2] Yang Jian zheng. Internet marketing tutorial [M]. Beijing: China Renmin University Press. 2002.

[3] Zhou Kai. 12008 On the trends in network marketing [J]. Internet Week, 2008, (5) :83-84.

[4] Yangsuyan. The road network marketing for SMEs [J]. Shanghai Information Technology 2008, (2) :68-70. 